is, yet it is very unlikely that any amount of argument would convince the writer in the 'Pall Mall Gazette' that he is guilty of a terrible mistake in judging of the insane consciousness from the revelations of a sane consciousness. In sober truth, however, he would not be one whit more unphilosophical were he to maintain that the fear of punishment should be used to prevent the convule sion of epilepsy or the spasm of chorea, because it may be successfully used to restrain the mischievous hands of a schoolboy. If he is truly anxious to judge the insane justly, he would do well for the future to try to conceive their mental state by the revelations of his own consciousness in dreams, or to accept the experience of those who have given their lives to the study of insanity.*

\title{
The trial of a Lunatic for Murder.
}

The following account of the trial of a lunatic for murder is interesting. The learned judge wisely stopped the trial, although it is probable that an ingenious counsel might have found in the prisoner's statements some ground for an argument that he knew the difference between right and wrong, as most lunatics notoriously do. "Something came over me. I seized my poor wife by the head, and knocked it against the flags again and again;" such is the articulate expression, as far as it can be articulately expressed, of that mental convulsion which in such case utters itself in homicide.

James Kelly was placed at the bar, charged with the wilful murder of his wife, Jane Kelly, at Butterworth, on the 1lth of June.

It appeared that the prisoner and his wife lived together at a place called Three Lanes-end, some three miles from Rochdale, and about a quarter of a mile from a place called Hollingworth Lake, a reservoir of the Rochdale Waterworks, upon which a steamboat and pleasure-boats were placed, having stalls and shops upon the edge, and which was turned to a place of public amusement. The prisoner by trade was a factory operative, but of late years had made his livelihood almost entirely by playing the accordion and concertina, and collecting money at the Hollingworth Lake, and he had married, within two years, a young woman named Royd, who had previously kept the school at the Three Lanes-end, and whose mother owned the cottage in which they subsequently lived. It appeared that the prisoner had at times given way to excessive drinking, as he himself said on one occasion, in consequence of frequenting the pleasure

- If anything could add force to these remarks, it is the result of the trial of Esther Lack, which has taken place since they were in type. The jury, before the termination of the evidence, expressed their opinion that she was insane; and in this opinion Mr. Justice Shee entirely concurred. 
parties at the Lake, but he had taken the pledge and then broken it, and it was said that he had been drinking heavily from the Wednesday till the following Tuesday in the week previous to the time of the murder, which was very early on Sunday morning, the 11th of June. A Mrs. Whitehead and a Mrs. Butterworth, with their husbands, were neighbours of the Kellys, and on the previous Thursday, hearing screams in the prisoner's cottage, they hurried there together, and found that the prisoner had been attempting to strangle his wife, and there were red marks indicating it upon her neck. He said that he had been doing so, and that she "would have been done for in two minutes if they had not come in." It appeared that the prisoner then produced a paper and asked his wife to read it, saying that it was an agreement to be hung together, but she said that she was so faint that she could not then. She, however, said, in answer to him, that it was true that they had agreed to be hung together. The next thing seen of them was on the Saturday night (that of the murder), when he was at the Butterworths' house, and his wife came to seek him. He referred to what he had tried on the Thursday, then sang snatches of hymns, and starting to his feet exclaimed, when he was told to go and take some sleep, that his wife "should never close her eyes in this world till she closed them in eternity." Notwithstanding this extraordinary conduct, the witnesses said he seemed to be sober at the time, but he referred to drink, and when told to abstain from liquor and that it was not too late, he said that it was; he had "made a mockery of God so often that he would not take Him in again." After this behaviour Mrs. Butterworth tried to persuade Mrs. Kelly not to go home with her husband that night, but the latter said that she was not afraid of him, and she would go back with her husband, and they went home between seven and eight in the evening. Later in the night, about midnight, the prisoner's next door neighbour, a man named Gibson, while at supper, heard the prisoner call on the Lord, and on Jesus, and praying very loud. At three in the morning the deceased woman came to his door and called him, saying her husband was dying, and on going in found him in bed praying, waving his arms, and declaring that he was dying of delirium tremens, very young, at the age of thirty-four. The witness took his hand, and found it cold and clammy.

At this point of the evidence the prisoner, who had behaved rather restlessly all through, and is a sullen-looking man, laughed out loudly, and shouted out, "That's a thumper, that's a thumper for you." He was then quiet again, sometimes looking round the court, and sometimes resting his head on the dock.

The witness continued, that his wife said, "Now he mentions drink, I sent for some yesterday, and after taking it he became calm." The prisoner objected to having any drink sent for, and 
said it was too late to have the doctor, and Gibson then went away, took a walk, and returning about five found the prisoner's door wide open as he passed it hastily to go into his own house. Mrs. Whitehead had also heard his shouting at 3 o'clock, and again at 5 o'clock further screaming and a groan. She looked out and saw Kelly washing his hands, which were bloody, in the well. He looked up at the house as he passed, and went away down the lane, having, it appeared, called at Gibson's for drink, but getting none and saying nothing more. Mrs. Whitehead gave the alarm, and the neighbours found the door of the prisoner's cottage wide open, with the feet of the body of the poor woman distinctly visible from the lane. The body was lain on its back, there being a night-dress on with a skirt over it, with many contusions on various parts of the head, face, and body, the jaw and collar-bone being broken, and a deep cut across the throat dividing the jugular. A large knife which had been wiped was lying on the breast, and the poker was found bloody, and a large iron candlestick was also found. The prisoner came along the road on the Sunday morning, towards Rochdale, and called at a man's house, a mile off, and asked for tobacco and to change hats with him. He was refused, and was found by a witness, who lived a little nearer to Rochdale, crouching in a pigstye, which was empty. Immediately he was seen he exclaimed, waving his hand, "Hush, hush, you mus'n't split and tell I am here." He gave the witness a shilling, asking him to get him some ale; but the latter having already heard of the murder, sent for assistance and took him into custody. He had blood upon his face and upon his clothes. One of the men said, "Kelly, you should not have done it." He said, "I have done it, and I shall have to stand the drop for it. I am one of the devil's children." He demanded the shilling back which he had given for drink. Dr. Lister was called to see him at the police station on the Sunday afternoon, and when he went in to him the prisoner started up and said, "Ah! its coming ;" and on being asked, "What P" answered, "Sulphur," adding that it was " Delightful," and, on the whole, giving the witness the impression at that time that his excitement was assumed. He talked much in the same way on other occasions subsequently, but the witness's impression seemed to incline in favour of the prisoner's sanity, although he admitted having heard him make a speech on the operations of intemperance, when he warned them against drink, and related how he had been tempted by it to throw himself into the lake. To the police-superintendent he made the following statement, "It was'n't me ; it was the devil. I had had half an hour's sleep, and I awoke when something came over me. I seized my poor wife by the head, and knocked it against the flags again and again. I then went out. She was not dead, but I could see nobody to whom I could report it. 
When I returned she was not dead. I could not bear to see her suffering, so I took the carving knife. I was praying before then beautifully to Jesus, and spoke to my wife about Jesus. I had been dozing about half an hour, when something came over me." It appeared that the prisoner had great influence over his wife, who had said that she was willing to die at any time.

The defence was that of insanity. The prisoner had always been excitable and peculiar, and had been known in Skipton, where he was born, when a boy, as "Silly Jemmy." A person called Harrison, a calico-printer at Burnley, who had known him all his life, was called to prove his early history; and another, who kept galvanic baths and had patients under his care, spoke to treatment of him under distinct attacks of disease of the brain. He did not know that these attacks were after periods of drinking, nor that the prisoner had indulged in laudanum and other stimulants than mere drink. It was five years since he had taken the pledge, but he had frequently broken it since, besides drinking much in the early part of his life. Other witnesses were called to prove his excitability and peculiarity at earlier periods of his life. A secretary to a temperance association proved that he travelled a regular circuit of temperance meetings, playing his accordion and addressing the audiences. Finally, Dr. Bromwell, medical officer to the Burnley Union, proved having attended the prisoner some years ago, and gave it as his distinct opinion that he was then suffering from physical disease of the brain.

After this evidence, his Lordship asked the learned counsel for the Crown whether it was desirable to proceed further, and Mr. Kay at oncè acceding to the suggestion, it was left to the jury to find whether the prisoner was insane or not, and they immediately returned a verdict of Acquittal on the ground of insanity.

His Lordship ordered the prisoner to be detained during Her Majesty's pleasure.

\section{Earl Russell on Capital Punishment.}

EarL Russeld, in his introduction to the new edition of his work on the "English Constitution" (1865), thus expresses himself as being favorable to the abolition of capital punishment :

"For my own part I do not doubt for a moment either the right of a community to inflict the punishment of death, or the expediency of exercising that right in certain states of society. But when I turn from that abstract right and that abstract expediency to our own state of society-when I consider how difficult it is for any judge to separate the case which requires inflexible justice from that 